\title{
Sea-ice-related halogen enrichment at Law Dome, coastal East Antarctica
}

\author{
Paul Vallelonga ${ }^{1}$, Niccolo Maffezzoli ${ }^{1}$, Andrew D. Moy ${ }^{2,3}$, Mark A. J. Curran ${ }^{2,3}$, Tessa R. Vance ${ }^{3}$, Ross Edwards ${ }^{4}$, \\ Gwyn Hughes $^{4}$, Emily Barker ${ }^{4}$, Gunnar Spreen ${ }^{5}$, Alfonso Saiz-Lopez ${ }^{6}$, J. Pablo Corella ${ }^{6}$, Carlos A. Cuevas ${ }^{6}$, and \\ Andrea Spolaor ${ }^{7,8}$ \\ ${ }^{1}$ Centre for Ice and Climate, Niels Bohr Institute, University of Copenhagen, Juliane Maries Vej 30, \\ Copenhagen $\emptyset$ 2100, Denmark \\ ${ }^{2}$ Australian Antarctic Division, Channel Highway, Kingston, TAS 7050, Australia \\ ${ }^{3}$ Antarctic Climate and Ecosystem Cooperative Research Centre, University of Tasmania, Private Bag 80, \\ Hobart, TAS 7001, Australia \\ ${ }^{4}$ Physics and Astronomy, Curtin University of Technology, Kent St, Bentley, WA 6102, Perth, Australia \\ ${ }^{5}$ University of Bremen, Institute of Environmental Physics, Otto-Hahn-Allee 1, 28359 Bremen, Germany \\ ${ }^{6}$ Department of Atmospheric Chemistry and Climate, Institute of Physical Chemistry Rocasolano, CSIC, \\ Serrano 119, 28006 Madrid, Spain \\ ${ }^{7}$ Ca'Foscari University of Venice, Department of Environmental Sciences, Informatics and Statistics, \\ Via Torino 155, 30170 Venice Mestre, Italy \\ ${ }^{8}$ Institute for the Dynamics of Environmental Processes, IDPA-CNR, Via Torino 155, 30170 Venice Mestre, Italy
}

Correspondence to: Paul Vallelonga (vallelonga@ nbi.ku.dk)

Received: 30 June 2016 - Discussion started: 13 July 2016

Revised: 29 December 2016 - Accepted: 10 February 2017 - Published: 27 February 2017

\begin{abstract}
The Law Dome site is ideal for the evaluation of sea ice proxies due to its location near to the Antarctic coast, regular and high accumulation throughout the year, an absence of surface melting or remobilization, and minimal multiyear sea ice. We present records of bromine and iodine concentrations and their enrichment beyond seawater compositions and compare these to satellite observations of first-year sea ice area in the $90-130^{\circ} \mathrm{E}$ sector of the Wilkes coast. Our findings support the results of previous studies of sea ice variability from Law Dome, indicating that Wilkes coast sea ice area is currently at its lowest level since the start of the 20th century. From the Law Dome DSS1213 firn core, 26 years of monthly deposition data indicate that the period of peak bromine enrichment is during austral spring-summer, from November to February. Results from a traverse along the lee (western) side of Law Dome show low levels of sodium and bromine deposition, with the greatest fluxes in the vicinity of the Law Dome summit. Finally, multidecadal variability in iodine enrichment appears well correlated to bromine enrich-
\end{abstract}

ment, suggesting a common source of variability that may be related to the Interdecadal Pacific Oscillation (IPO).

\section{Introduction}

Atmospheric halogen chemistry is highly complex and has been a topic of intensive study over the past 3 decades (SaizLopez and von Glasow, 2012; Simpson et al., 2015). A major branch of this research involves the occurrence of enhanced concentrations of boundary-layer bromine in coastal Antarctica, which has been linked to the depletion of tropospheric ozone and mercury (Simpson et al., 2015). Tropospheric ozone is critical to solar forcing, UV absorption and aerosol formation in the polar regions whereas the concentration of mercury in polar snow is a matter of great concern for Arctic ecosystems in the future (Brooks et al., 2006; Hylander and Goodsite, 2006). Recent studies indicate that boundary layer bromine is driven by photochemical recycling above the salt-rich snow and ice surfaces, with such recycling predominantly occurring in the austral spring, when 
the concentration of surface salts and surface area of firstyear sea ice are at their greatest (Pratt et al., 2013; Zhao et al., 2016). Photochemical recycling of bromine primarily involves heterogeneous reactions of halide salts (such as $\mathrm{HOBr}$ and $\mathrm{BrONO}_{2}$ ) in sea ice and snowpack leading to the emission of $\mathrm{Br}_{2}$ molecules. $\mathrm{Br}_{2}$ is then photodissociated into two $\mathrm{Br}^{-}$radicals that are available for further heterogeneous chemical recycling. Bromine explosion events primarily occur in early spring and summer, although winter sources of organohalide emissions have also been observed in coastal polar regions, although the relative influence of such sources is still a topic of investigation (Impey et al., 1997; Nerentorp Mastromonaco et al., 2016; Simpson et al., 2007).

The processes and physical conditions underlying photochemical bromine recycling events, commonly called "bromine explosions", are subject to investigation through a combination of satellite and in situ observations as well as chemical transport modelling. Bromine and sodium in coastal Antarctic air are predominantly sourced from sea salts, but only bromine is enriched by bromine explosion events. Processes and precursors of halogen recycling in polar regions include: the role of acids in snowpack in enhancing heterogeneous bromine production; the role of organic molecules as sources of radicals - particularly in the Arctic, where formaldehyde and other organic pollutants may be present in significant concentrations; and the partitioning of bromine between gas and particulate phases in snowpack and boundary layer air. The transport of bromine is being understood through a combination of ground and satellitebased measurements combined with simple models that incorporate explicit snowpack chemistry (Spolaor et al., 2016b; Zhao et al., 2016). These models demonstrate the importance of such features as wind velocity and vertical mixing (boundary-layer turbulence) as well as the surface parameters mentioned above (Toyota et al., 2014). In situ observations of halogens in both gaseous and aerosol forms (Legrand et al., 2016) are essential to understanding halogen deposition and recycling processes in polar regions and improve current atmospheric models.

Reactive iodine has a global influence on ozone depletion and the oxidizing capacity of the polar atmosphere by influencing the repartitioning of $\mathrm{HO}_{x}$ and $\mathrm{NO}_{x}$ (Saiz-Lopez et al., 2012). In particular, large amounts of oxidized iodine detected by a ground-based spectrometer were observed in coastal Antarctica (Saiz-Lopez et al., 2007) highlighting these coastal areas as iodine hotspots. Enhanced sea ice bioproductivity during springtime and winter organic emissions have been suggested as the main sources of iodine in the Antarctic Peninsula (Atkinson et al., 2012; Granfors et al., 2014; Saiz-Lopez et al., 2015). Recent iodine instrumental measurements in the Antarctic coastal sea ice zone showed that $I_{2}$ dominates the iodine atom fluxes to the atmosphere (Atkinson et al., 2012). The same study revealed that iodocarbon concentrations above sea ice brines were over 10 times greater than those of the seawater below.
The first measurements of bromine and iodine species (bromide $\mathrm{Br}^{-}$and bromate $\mathrm{BrO}_{3}^{-}$, iodide $\mathrm{I}^{-}$and iodate $\mathrm{IO}_{3}^{-}$) in Antarctic ice were reported by Spolaor et al. (2012) indicating relatively stable concentrations of 100$200 \mathrm{pg} \mathrm{Br}^{-} \mathrm{g}^{-1}$ and 5-32 $\mathrm{pg} \mathrm{I}^{-} \mathrm{g}^{-1}$ in Talos Dome ice core from the early Holocene. Bromate and iodate were not present above detection limits $\left(38 \mathrm{pg}^{\mathrm{BrO}}-\mathrm{g}^{-1}, 7 \mathrm{pg}\right.$ $\mathrm{IO}_{3}^{-} \mathrm{g}^{-1}$ ) in these samples. Subsequently, total bromine concentrations in the Talos Dome ice core were reported for the past two glacial cycles, observing a depletion of bromine relative to the $\mathrm{Br} / \mathrm{Na}$ ratio found in seawater during the last two glacial maxima (Spolaor et al., 2013b). The temporal variability of bromine depletion corresponded well with a reconstruction of sea ice duration in the Victoria Land sector (Crosta et al., 2004), opening a basis for the further investigation of links between sea ice extent and bromine in polar ice cores. The seasonal nature of bromine enrichment in Antarctic ice was demonstrated by Spolaor et al. (2014), who reported spring/summer peaks of bromine enrichment and winter peaks of iodine concentration in Law Dome ice dating to 1910-1914 CE.

Reconstruction of Antarctic sea ice from ice-core-based proxies is primarily based on fluxes of sodium and/or methanesulfonic acid (MSA, $\mathrm{CH}_{3} \mathrm{SO}_{3}^{-}$) (e.g., Abram et al., 2013; Curran et al., 2003). In the EPICA Dome $C$ ice core, sodium concentrations were investigated by Röthlisberger et al. (2010) and compared to sea ice reconstructions from Southern Ocean marine sediment cores. For the last two glacial cycles, good correspondence was found between seasalt-derived sodium and the marine record. For reconstruction of sea ice area on decadal or even centennial scales, the influence of meteorological and depositional noise has been shown to be an important factor to consider especially for drill sites located far inland such as Dome C (Levine et al., 2014).

In contrast, the presence of MSA in ice cores has been successfully linked to observed sea ice variability in some Antarctic ice cores (e.g., Abram et al., 2007, 2013). In some cases, the presence of MSA is either positively or negatively correlated with sea ice, depending on such factors as local wind direction, polynya and sea ice seasonality (Abram et al., 2013). The longest reconstruction of sea ice extent using MSA has been reported for Law Dome, East Antarctica (Curran et al., 2003) covering the past 200 years and indicating a steady decrease in sea ice extent to the year $2000 \mathrm{CE}$. Recent satellite observations report a slow increase in Antarctic sea ice over the past 3 decades (Parkinson and Cavalieri, 2012), and other MSA-based sea ice reconstructions support such observations (Thomas and Abram, 2016).

In this work, we report halogen deposition from the Dome Summit South (DSS), Law Dome ice core record covering the 20th century, with an emphasis on high-resolution measurements corresponding to the period since satellite observations of sea ice began. We examine correlations between 
sea ice area and bromine as well as halogen enrichment in the DSS Law Dome ice cores. The high rate of snow accumulation and regular year-round snowfall at Law Dome makes the site ideal for such a study, as well as the detailed MSAbased sea ice reconstruction already reported for the site. Although MSA originates from a different emission source than bromine, both are related to sea ice area and hence should be expected to produce an overall similar pattern of sea ice variability on a multi-year or decadal scale.

\section{Methods}

\subsection{Sample collection}

\subsubsection{Dome Summit South (DSS), Law Dome}

The DSS ice cores are from Law Dome, East Antarctica. Law Dome is a small ice cap located approximately $120 \mathrm{~km}$ inland from the Wilkes Land coast (Fig. 1). The summit of Law Dome experiences relatively high and constant year-round precipitation, providing clear seasonal variability in stable isotopes of water and ionic species (Curran et al., 1998; McMorrow et al., 2004). The summit of Law Dome features a snow accumulation rate of approximately $60 \mathrm{~cm}$ ice equivalent per year, with an average annual temperature of $-20^{\circ} \mathrm{C}$. The precipitation is predominantly due to westerly cyclonic systems which produce a strong accumulation gradient from east (high accumulation) to west (low accumulation). The Law Dome summit is at an altitude of $1310 \mathrm{~m}$ a.s.l., above approximately $1200 \mathrm{~m}$ of ice dating back to the last glacial (Morgan et al., 1997). The ice core samples were collected from the DSS site that is within a few hundred metres of the Law Dome summit, with the specific coordinates and sampling details described in the following sections. In all cases, the samples described here have been dated by identification and counting of annual cycles in stable isotopes of water (Morgan and van Ommen, 1997; Roberts et al., 2015) and ionic species (Curran et al., 1998) as well as synchronization of well-dated volcanic eruption tie points (Plummer et al., 2012). Impurities in Law Dome snow are dominated by sea salt inputs ( $98 \%$ by mass) with a minor input from mineral dust ( $2 \%$ by mass) (Vallelonga et al., 2004).

\subsubsection{DSS0506}

A $258 \mathrm{~m}$ deep ice core was drilled using a $20 \mathrm{~cm}$ diameter thermal drill near to the Law Dome summit $\left(66^{\circ} 46^{\prime} 19.68^{\prime \prime} \mathrm{S}\right.$, $112^{\circ} 48^{\prime} 25.60^{\prime \prime} \mathrm{E}$ ) in November 2005 (Burn-Nunes et al., 2011). The core, designated DSS0506, was subsampled in October 2006 in a cold laboratory in a storage freezer in Hobart. For each $\sim 1 \mathrm{~m}$ long section of ice, a $35 \mathrm{~mm} \times 35 \mathrm{~mm}$ stick was collected for chemical analysis, and subsequently decontaminated by chiselling with a microtome blade in an HEPA-filtered laminar flow bench in a freezer. All equipment used for the decontamination was repeatedly

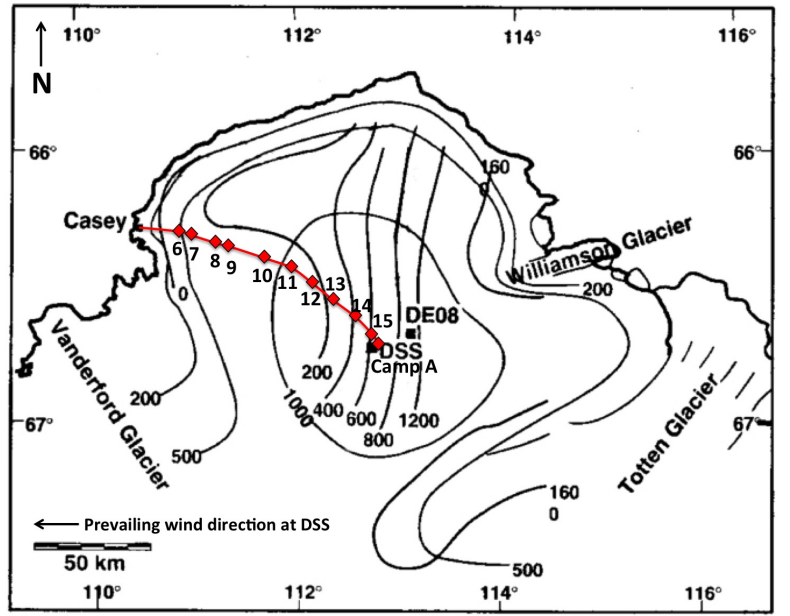

Figure 1. Map of Law Dome with contours of elevation (ma.s.1.) and accumulation $\left(\mathrm{kg} \mathrm{m}^{-2} \mathrm{a}^{-1}\right)$. The red line indicates the traverse route from Casey station to Camp A located near the Law Dome Summit. Red diamonds indicate the Law Dome Traverse (LDT) surface snow sampling stations. DSS1516, DSS1213 and DSS0506 sampling sites are all in the vicinity of Camp A.

cleaned and stored in deionized water (Millipore MQ system, $18.2 \mathrm{M} \mathrm{cm}^{-1}$ ). The decontaminated samples were collected in polystyrene "Coulter counter" accuvettes and then melted for analysis by ion chromatograph. The remaining melted sample, usually 3 to $8 \mathrm{~mL}$, was then refrozen and stored. In 2014 the remaining samples were sent to the University $\mathrm{Ca}$ ' Foscari of Venice for bromine determination. The depth range of DSS0506 samples reported here is from $19.7 \mathrm{~m}$ (1991 CE) to $72.5 \mathrm{~m}$ (1929 CE). The sampling resolution increased with depth, from $5 \mathrm{~cm}$ near the surface to $3 \mathrm{~cm}$ at depth, ensuring higher than monthly resolution at approximately 25 and 15 samples per year, respectively.

\subsubsection{DSS1213}

In austral summer 2012/2013, a $30 \mathrm{~m}$ firn core was drilled at DSS, Law Dome $\left(66^{\circ} 46^{\prime} 21^{\prime \prime} \mathrm{S}, 112^{\circ} 48^{\prime} 40.59^{\prime \prime} \mathrm{E}\right)$ using the 4 in. Kovacs Mark VI coring system (Roberts et al., 2015). The firn core was transported to Hobart, Australia, and subsampled in the freezer at the Australian Antarctic Division (AAD)/Antarctic Climate and Ecosystem CRC (ACE CRC). For each $1 \mathrm{~m}$ length of firn, a $35 \mathrm{~mm} \times 35 \mathrm{~mm}$ stick was cut and sent to the Trace Research Advanced Clean Environment (TRACE) laboratory at Curtin University of Technology, Perth, Western Australia, for bromine determination. A parallel $35 \mathrm{~mm} \times 35 \mathrm{~mm}$ stick was decontaminated and analysed for trace ions at the AAD/ACE CRC in Hobart, with a parallel section analysed for stable isotopes of water. Data covering the full depth range of the firn core are reported here, covering the period from summer 2012/2013 to late 1987 and overlapping with the DSS0506 record. 


\subsubsection{Law Dome traverse and DSS1516 snowpit}

Another sampling expedition was conducted at Law Dome summit in February 2016, with snow surface samples collected during the traverse to the DSS site and from a $1 \mathrm{~m}$ snowpit. The DSS1516 snowpit $\left(66^{\circ} 46^{\prime} 23.51^{\prime \prime} \mathrm{S}\right.$, $\left.112^{\circ} 48^{\prime} 40.59^{\prime \prime} \mathrm{E}\right)$ was collected upwind from the traverse camp (designation: Waypoint A, $66^{\circ} 46^{\prime} 22.12^{\prime \prime} \mathrm{S}$, $112^{\circ} 48^{\prime} 28.19^{\prime \prime} \mathrm{E}$ ) and sampling was conducted immediately after the pit was prepared. Samples were collected every $3 \mathrm{~cm}$ by plunging pre-cleaned $50 \mathrm{~mL}$ polyethylene tubes into the pit wall. Stable isotopes of water $\left(\delta^{18} \mathrm{O}\right.$ and $\left.\delta \mathrm{D}\right)$ measured in the parallel snow pit wall confirm that the $1 \mathrm{~m}$ sequence covers the period from winter (July) 2015 to February 2016.

In addition to the DSS1516 snowpit, surface snow samples were collected during a 1-day traverse from Casey station to the DSS Campsite A. Details of the sampling sites are included in Table S1 (Supplement). Eleven samples were collected during the $114 \mathrm{~km}$ traverse, extending from an altitude of 500 to $1320 \mathrm{~m}$ a.s.1. at the DSS1516 site. The samples were collected every 10 to $15 \mathrm{~km}$ by moving approximately $15 \mathrm{~m}$ upwind of the Hagglunds traverse vehicle and plunging a polyethylene tube into the snow surface. The tubes were immediately sealed after sampling and were kept frozen until analysis. All samples collected during the Casey-Law Dome traverse and from the DSS1516 snowpit were sent to the TRACE laboratory at Curtin University of Technology for bromine analysis.

\subsection{Halogen measurements}

\subsubsection{Australia}

The DSS1213 $1 \mathrm{~m}$ sticks were cut and prepared in the TRACE laboratory located at Curtin University of Technology, Perth, Australia (Ellis et al., 2015) and measured in June 2015. The $35 \mathrm{~mm} \times 35 \mathrm{~mm}$ cross-section sticks were melted on a silicon carbide melter head at a melt rate of $5 \mathrm{~cm} \mathrm{~min}^{-1}$ following the setup of McConnell et al. (2002), with a depth resolution of less than $1 \mathrm{~mm}$. The central melt line was directed to a Thermo Element XR ICP-SFMS fitted with cyclonic Peltier-cooled spray chamber $\left(2^{\circ} \mathrm{C}\right)$ and $400 \mu \mathrm{L} \mathrm{min}^{-1}$ PFA ST nebulizer (both from ESI, Omaha, USA). The sample line was acidified with $2 \%$ ultrapure nitric acid and internal standard (4 ppb $\left.{ }^{115} \mathrm{In}\right)$ immediately before introduction to the plasma. Only bromine and sodium were determined, at medium resolution $(\sim 4000)$, in the DSS1213 firn core.

Law Dome traverse and DSS1516 snowpit samples were analysed in February 2016 using a non-continuous SeafastII autosampler with syringe pump connected to the abovementioned analytical system. For these samples, iodine $\left({ }^{127} \mathrm{I}\right)$ was determined at low mass resolution $(\sim 300)$ and all other elements at medium resolution $\left({ }^{23} \mathrm{Na},{ }^{35} \mathrm{Cl},{ }^{79} \mathrm{Br}\right)$. A $4 \mathrm{ppb}$ ${ }^{115}$ In internal standard was used at both mass resolutions. Analytical blanks and quality control standards were determined after every 10 samples analysed.
Irrespective of the sample delivery method, the analytical performance of the Element XR ICP-SFMS was consistent during the measurement campaigns. Calibration standards were prepared by sequential dilution from primary stock solutions (bromine, $10 \mu \mathrm{g} \mathrm{mL}^{-1}$ in $\mathrm{H}_{2} \mathrm{O}$; sodium, $1000 \mu \mathrm{g} \mathrm{mL}^{-1}$ in $1 \% \mathrm{HNO}_{3}$ ) from high-purity standard (Charleston, USA). Sodium and bromine were calibrated using seven concentration standards of increasing concentration up to $100 \mathrm{ppb}$ (sodium) and $4 \mathrm{ppb}$ (bromine). All linear calibration regressions showed $R^{2}>0.99(n=8, p<0.001)$. Detection limits for bromine and sodium were 0.18 and $1.1 \mathrm{ppb}$ respectively $(n=80)$ Repeatability of measurements was systematically tested in each analytical run by measuring replicates of quality-controlled standards. The variability was calculated as the standard deviation of the signals and found to be $9 \%$ for bromine and $4 \%$ for sodium.

\subsubsection{Italy}

The DSS0506 core samples were measured at the Environmental Analytical Chemistry laboratory of the University Ca' Foscari of Venice in March 2014. The samples were stored in plastic vials and were kept frozen until analysis. For the DSS0506 samples, some of the polystyrene accuvettes were broken in transport and were found to be contaminated upon comparison of sodium concentrations measured before and after transport. Consequently, data corresponding to the years 1945/1946, 1950/1951, 1954/1955 and 1963/1964 are incomplete.

Similar to the Curtin University analysis, samples were measured on a Thermo Element2 ICP-SFMS instrument using a cyclonic peltier-cooled spray chamber (ESI, Omaha, USA). System cleaning and operational parameters have been described previously (Spolaor et al., 2013b) and will be summarized here. Before beginning each analytical session, the sample introduction system was cleaned with alternating washes of $5 \% \mathrm{NH}_{4} \mathrm{OH}$, then $2 \% \mathrm{HNO}_{3}$ acid, separated by $30 \mathrm{~s}$ of MQ water. During the analytical sessions, the sample line was thoroughly cleaned using $2 \%$ nitric acid (120s) and UPW (120s) between each analysis. Elements were determined in low $\left({ }^{127} \mathrm{I}\right)$ and medium resolution $\left({ }^{23} \mathrm{Na}\right.$, ${ }^{79} \mathrm{Br}$ ) with plasma stability evaluated by the continuous monitoring of ${ }^{129} \mathrm{Xe}$. External standards, ranging from 0.01 to $4 \mathrm{ppb}$, were prepared by diluting a $1000 \mathrm{ppm}$ stock IC solution (TraceCERT ${ }^{\circledR}$ purity grade, Sigma-Aldrich, MO, USA). Excellent precision was found with calibration correlations of $R^{2}>0.99(N=6, p=0.05)$. Calculated detection limits were $0.05 \mathrm{ppb} \mathrm{Br}, 0.005 \mathrm{ppb}$ I and $0.8 \mathrm{ppb} \mathrm{Na}$.

The reproducibility of measurements between the two laboratories was tested by analysing 140 Greenland snow pit samples in both laboratories (Venice, December 2015; Perth, February 2016). Compatibility of the measurements (Figs. S1 and S2) showed a regression line with $R^{2}>0.9(n=140, p<0.05)$ for both analytes. Distributions of residuals show an average measurement offset 
of $-0.64 \pm 0.19 \mathrm{ppb}$ (sodium, RSD $=2.0 \pm 0.2 \mathrm{ppb)}$ and $-0.03 \pm 0.01 \mathrm{ppb}$ (bromine, $\mathrm{RSD}=0.11 \pm 0.01 \mathrm{ppb}$ ). The $\mathrm{Na}$ and $\mathrm{Br}$ data series regression gradients (Figs. S1 and S2) indicate an offset of $8 \pm 2 \%$ between the measurements of the two laboratories, which we attribute to differences in the overall accuracy of the standard calibrations applied to the raw data on the basis of the $8 \%$ deviation being consistent for both elements. If the offset were due to element-specific bias such as differential ionization efficiencies or variable blank corrections, the offset would not be consistent between the two elements. Ultimately, the influence of this minor offset is negated by our use of bromine enrichment values, which are calculated as the element concentration ratios (Sect. 3.1).

\subsection{Ion chromatography measurements}

Major and minor ions were determined at the AAD/ACE CRC laboratory in Hobart, Australia, following the established suppressed ion chromatographic methods (Curran and Palmer, 2001). Samples were stored and prepared in a HEPAfiltered clean room and all laboratory apparatus was cleaned using filtered deionized water (Siemens ultrapure water system, $18.2 \mathrm{M} \Omega \mathrm{cm}^{-1}$ ). Detection limits for MSA and Na were 0.095 and $0.23 \mathrm{ppb}$, with reported precisions of 3.8 and $0.46 \mathrm{ppb}$ and analytical ranges of $0.6-40$ and $0.7-500 \mathrm{ppb}$, respectively. The MSA data covering the period 1920-1995 are those reported by Curran et al. (2003). Sodium data from the DSS main ice core record have been previously discussed by Palmer et al. (2001).

\subsection{Sea ice area}

Satellite-based observations of sea ice area and concentration have been used to evaluate the suitability of bromine and iodine as proxies for sea ice area reconstructions. We have calculated sea ice area as the product of sea ice concentration and grid cell size for each grid cell in the two sectors considered. Note that sea ice area is different to, and slightly less than, sea ice extent, as sea ice extent is commonly defined as the sum of grid cells containing at least $15 \%$ sea ice coverage. The sea ice area has been evaluated in two ocean sectors adjacent to Law Dome and are used for comparison: one to the west of Law Dome $\left(90-110^{\circ} \mathrm{E}\right)$ and one to the east of Law Dome $\left(110-130^{\circ} \mathrm{E}\right)$; as shown in Fig. 2. A strong east-to-west accumulation gradient has been observed across Law Dome. Hence it is expected that sea salts carried to Law Dome will predominantly originate from low-pressure systems developing from the $90-110^{\circ} \mathrm{E}$ sector.

A discontinuous record of monthly sea ice area is calculated from a series of satellite-based sensors, covering the period from 1974-2015 with missing years for 1975, 1977 and 1978. Sea ice area for the period 1973-1977 was determined from daily brightness temperatures monitored by the ESMR instrument mounted on the NIMBUS-5 satellite (Parkinson et al., 2004). For the period January 1979 to May 2015, sea

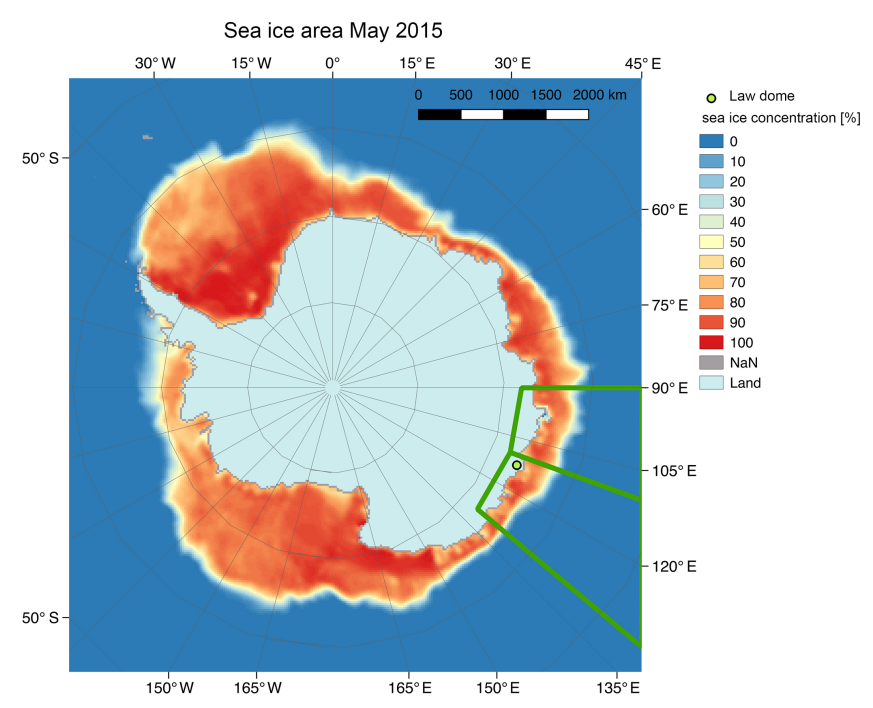

Figure 2. Antarctic sectors used for evaluating sea ice trends. Two sectors $\left(90-110^{\circ} \mathrm{E}\right.$ and $\left.110-130^{\circ} \mathrm{E}\right)$ adjacent to Law Dome have been isolated and used to calculate past sea ice area. The image shows and example of sea ice area for the month of May 2015 given as sea ice concentration (\%) per grid cell.

ice observations were obtained from the SMMR and SSM/I and SSMIS instruments mounted on various satellite platforms (Cavalieri et al., 1996). These data are freely available from the US National Snow and Ice Data Centre (NSIDC) website (Cavalieri et al., 1999; Fetterer et al., 2002).

First-year sea ice (FYSI) area has been calculated as the difference between the late-summer (February/March) minimum and late-winter (September/October) maximum of sea ice area occurring each year. FYSI data series' calculated for the $90-110^{\circ} \mathrm{E}$ and $110-130^{\circ} \mathrm{E}$ sectors are shown in Fig. 3. Also shown in Fig. 3 are two other publicly available datasets reporting sea ice extent (not sea ice area), largely calculated from the same satellite observations. The first dataset, here referred to as "Jacka SIE", reports monthly observations of the northernmost sea ice edge (SIE) for $10^{\circ}$ sectors of longitude around Antarctica over the period 1973-1998. The data are available online (https://data.aad.gov.au/metadata/ records/climate_sea_ice) and were employed by Curran et al. (2003) to validate their MSA-based Law Dome sea ice reconstruction. The second dataset is produced by National Snow and Ice Data Centre (NSIDC) and offers near-daily sea ice extent over the period 1978-2013 for Antarctica. The data are divided into five Antarctic sectors, of which the "Pacific Ocean" sector encompasses $90-160^{\circ} \mathrm{E}$ and includes Law Dome. The Jacka SIE and NSIDC datasets are shown to demonstrate their general correspondence with the FYSI data reported here for regression analysis with Law Dome bromine data. In Fig. 3, we also plot the sum of the $90-110^{\circ} \mathrm{E}$ and $110-130^{\circ} \mathrm{E}$ FYSI datasets to allow better comparison to Jacka SIE and NSIDC. 


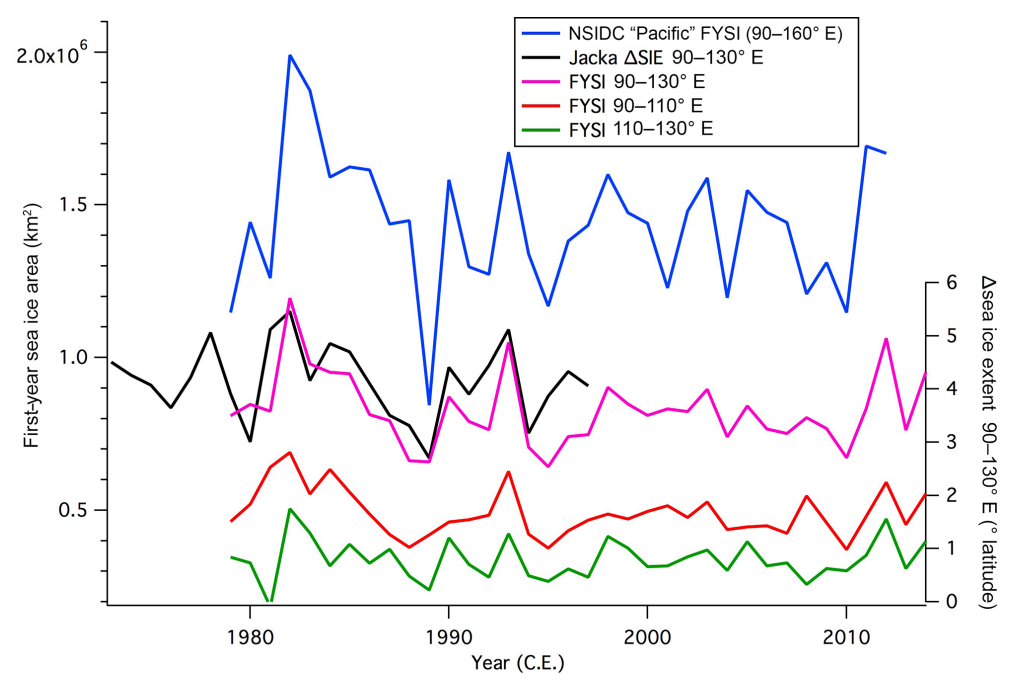

Figure 3. First-year sea ice (FYSI) areas calculated from satellite microwave radiometer observations. The $90-110^{\circ} \mathrm{E}$ and $110-130^{\circ} \mathrm{E}$ data shown here correspond to the two sectors indicated in Fig. 2. The 90-130 E FYSI data series (fuchsia) is the sum of the $90-110^{\circ} \mathrm{E}$ (red) and $110-130^{\circ} \mathrm{E}$ (green) data series. For comparison to previous studies, we include corresponding data series from Jo Jacka (Jacka, 1998) and NSIDC (Fetterer et al., 2002). Note that the NSIDC Pacific sector covers a larger sector $\left(90-160^{\circ} \mathrm{E}\right)$ than the other records shown here.

\section{Results and discussion}

\subsection{Halogen and sodium records}

Mean bromine, iodine and sodium glaciochemical concentrations (1927-2012 CE for $\mathrm{Br}$ and $\mathrm{Na}, 1927-1989 \mathrm{CE}$ for I) at DSS were comparable to previously reported values for Law Dome (Curran et al., 1998; Spolaor et al., 2014). Considering annual averages over the period 1927-2012, we find average concentrations of $88 \pm 45(1 \sigma) \mathrm{ng} \mathrm{g}^{-1}$ for $\mathrm{Na}$ and $2.9 \pm 2.7(1 \sigma) \mathrm{ng} \mathrm{g}^{-1}$ for Br. For iodine, the average for the period $1927-1989$ is $0.061 \pm 0.023 \mathrm{ng} \mathrm{g}^{-1}(1 \sigma, n=62)$. As may be expected from the "spiky" nature of the data, both the medians (81.1 ng Na g ${ }^{-1}, 2.1 \mathrm{ng} \mathrm{Br} \mathrm{g}^{-1}, 0.056 \mathrm{ng} \mathrm{Ig}^{-1}$ ) and geometric means of the data $\left(81.0 \mathrm{ng} \mathrm{Na} \mathrm{g}^{-1}, 2.3 \mathrm{ng} \mathrm{Br} \mathrm{g}^{-1}\right.$, $0.057 \mathrm{ng} \mathrm{Ig}^{-1}$ ) are 5 to $20 \%$ lower than the arithmetic means. Annually averaged non-sea-salt $\mathrm{Br}$ (nssBr) concentrations average $2.4 \mathrm{ng} \mathrm{g}^{-1}$ (geomean $1.6 \mathrm{ng} \mathrm{g}^{-1}$ ) are comparable to values reported previously for Law Dome (Spolaor et al., 2014). Sodium concentrations are also in good agreement with previously reported values of $3.47 \pm 3.03(1 \sigma) \mu \mathrm{eq} \mathrm{L}^{-1}$ $\left(80 \pm 70 \mathrm{ng} \mathrm{g}^{-1}\right)$ (Curran et al., 1998).

The bromine, iodine and sodium time series records determined for DSS firn and ice cores are shown in Fig. 4. No significant trend is present in any of the time series. The sodium data are representative of sea salt inputs from the Southern Ocean to the site whereas bromine is known to be subject to enhancement in photochemical "bromine explosion" events. We quantify the strength of such photochemical enrichment by calculating the bromine enrichment $\left(\mathrm{Br}_{\mathrm{enr}}\right)$ beyond the bromine/sodium abundance ratio found ubiquitously in seawater $(\mathrm{Br} / \mathrm{Na}=0.006$; Turekian, 1968). Following common practice (e.g. Spolaor et al., 2013a, 2016a) we calculate
$\mathrm{Br}_{\text {enr }}=\mathrm{Br}_{\text {conc }} /\left(\mathrm{Na}_{\text {conc }} \times 0.006\right)$, where $\mathrm{Br}_{\text {conc }}$ and $\mathrm{Na}_{\text {conc }}$ respectively describe the concentrations of $\mathrm{Br}$ and $\mathrm{Na}$ measured in a sample. For iodine enrichment $\left(\mathrm{I}_{\mathrm{enr}}\right)$ we apply the same enrichment calculation but using the iodine/sodium ratio in seawater of $5.93 \times 10^{-6}$ (Turekian, 1968). Iodine and bromine enrichment data and their relation to sea ice variability will be discussed in the following sections.

There appears to be less interannual variability in the DSS1213 $\mathrm{Br}$ record, with respect to the DSS0506 record. The average values of $\mathrm{Br}_{\mathrm{enr}}$ and $\mathrm{Br}_{\text {conc }}$ are similar for the two cores but the variance of annual averages is much greater for the DSS0506 samples (Table 1). For sodium, there is no substantial difference in average concentration but the opposite trend is found for variance, with greater variance in the DSS1213 data. We attribute this difference in variance to the different sampling and analytical techniques applied to each core - DSS0506 was sampled by discrete chiselling and DSS1213 sampled by continuous melting. The ice core melter system had a flow path $\sim 5$ times longer than the discrete sampling system, and there was likely greater memory effect of bromine coating onto the inside of the ICP-SFMS sample introduction system (peltier-cooled cyclonic spray chamber) used for the continuous melting analysis. Note that the memory effect is much more significant for bromine than for sodium, which is efficiently transported through the ICPSFMS spray chamber in $\mathrm{HNO}_{3}$ acid solution. Sodium does not have a significant memory effect and the higher variance found by the ice core melter is expected due to the higher depth resolution of the melter system compared to discrete sampling. Despite the apparent aliasing of the DSS1213 Br record, the two records show good agreement in the overlap period from calendar 1988 to 1989 (Fig. 4). A double peak 


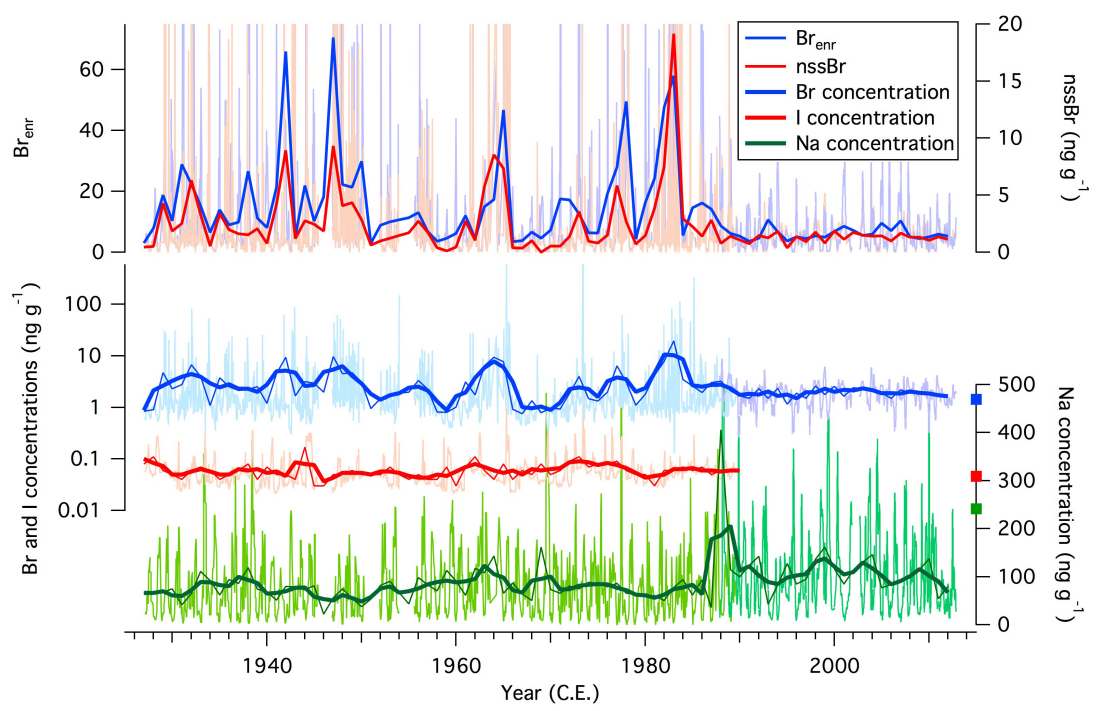

Figure 4. Time series of sodium, iodine and bromine concentrations as well as nssBr and $\mathrm{Br}_{\text {enr }}$ at Law Dome. Raw data are shown in pale colours, with annual means shown by a thin line and 3-year running means shown by a thick line. For nssBr and Brenr, only raw data (pale colours) and annual averages (thick line) are shown. Different shades of blue and green are used to distinguish data from DSS0506 (1927-1989) and DSS1213 (1987-2013). The squares indicate average values from the DSS1516 snow pit.

in $\mathrm{Br}$ was found with the initial peak in the DSS0506 core leading the DSS1213 record by approximately 2 weeks (from comparison of the timescales), which is well within the subannual dating error. Furthermore the seasonality of bromine and sodium measured in the DSS1213 samples (discussed in Sect. 3.5) are in agreement with previous studies conducted on Law Dome samples (Curran et al., 1998; Spolaor et al., 2014).

\subsection{Bromine and first-year sea ice}

Considering the known relationships between emissions of bromine and seasonal sea ice area, we investigated the reliability of bromine, and bromine enrichment, as a proxy for regional seasonal sea ice area adjacent to Law Dome. With the intention of reducing data autocorrelation, we transform the $\mathrm{Br}_{\text {enr }}$ data to a Gaussian-like distribution using the natural logarithm of $\mathrm{Br}_{\text {enr }}$ for correlation to FYSI data. An additional reason for applying a logarithmic transformation is due to the exponential nature of the "bromine explosion" process occurring above the bromine-rich FYSI surface: in each stage of the explosion, one reactive bromine species ( $\mathrm{HOBr}$ ) is consumed in the process of liberating $\mathrm{Br}_{2}$ from the sea ice surface. $\mathrm{As}_{\mathrm{Br}}$ is the reactive precursor to two subsequent bromine explosion multiphase reactions, the process develops exponentially. Histograms of $\mathrm{Br}$ concentration, $\mathrm{Br}_{\mathrm{enr}}$ and $\ln \left(\mathrm{Br}_{\mathrm{enr}}\right)$ are shown in Fig. S3, demonstrating that the distribution of $\ln \left(\mathrm{Br}_{\mathrm{enr}}\right)$ values in Law Dome is well represented by a Gaussian curve. Correlation tests have been performed using different subsets of the $\ln \left(\mathrm{Br}_{\mathrm{enr}}\right)$ data; such as summer-summer (calendar year), winter-winter (July-June) and spring-only (August-October) intervals. The FYSI data used for correlation has been described in Sect. 2.4. Note that the optimal correlation is found when $\ln \left(\mathrm{Br}_{\mathrm{enr}}\right)$ is compared to the FYSI value from the previous year. This is due to the timing of formation of sea ice in the Antarctic (from March to September) occurring, by necessity, earlier than the springtime bromine explosion that occurs in the following calendar year.

A summary of the correlation analysis between Law Dome bromine enrichment and FYSI is shown in Table 2. We observe firstly that $\ln \left(\mathrm{Br}_{\text {enr }}\right)$ is better correlated with the 90 $110^{\circ} \mathrm{E}$ sector than for the $110-130^{\circ} \mathrm{E}$ sector. Such a finding is consistent with the westerly circulation around Antarctica, despite the individual cyclonic systems producing an east-to-west deposition gradient across Law Dome. The 80 $140^{\circ} \mathrm{E}$ sector was used for correlation between sea ice extent and MSA concentrations at Law Dome (Curran et al., 2003), with the best correlation found for sea ice in the $110^{\circ} \mathrm{E} \mathrm{sec}-$ tor. The strongest correlation $\left(r^{2}=0.357, p<0.001\right)$ is between $\ln \left(\mathrm{Br}_{\text {enr }}\right)$ and $90-110^{\circ} \mathrm{E}$ sector FYSI for the summersummer calendar year period. A weaker and less significant correlation is found between $\ln \left(\mathrm{Br}_{\mathrm{enr}}\right)$ and $110-130^{\circ} \mathrm{E}$ FYSI for the winter-winter interval $\left(r^{2}=0.20, p<0.01\right)$. Such a finding is counter-intuitive because the bromine explosion occurs primarily in spring/summer and should be most completely captured in the winter-winter interval. As has been demonstrated thoroughly by Levine et al. (2014), meteorological transport variability and other "noise effects" can have a strong influence on the regularity of seasonal sea salt deposition. Hence it may be that the summer-summer interval produces a marginally stronger correlation with 90 
Table 1. Statistical summary of time series data presented from Law Dome Summit South (DSS) ice cores.

\begin{tabular}{|c|c|c|c|c|c|c|c|c|c|c|c|c|}
\hline \multirow{2}{*}{$\begin{array}{l}\text { Sample } \\
\text { designation }\end{array}$} & \multirow{2}{*}{$\begin{array}{l}\text { Time } \\
\text { interval }\end{array}$} & \multirow{2}{*}{$\begin{array}{l}\text { No. } \\
\text { years }\end{array}$} & \multicolumn{3}{|c|}{ Sodium (ppb) } & \multicolumn{3}{|c|}{ Bromine (ppb) } & \multicolumn{2}{|c|}{ Ln (Brconc) } & \multicolumn{2}{|c|}{ Ln (Brenr) } \\
\hline & & & mean & median & variance & mean & median & variance & mean & variance & mean & variance \\
\hline DSS1516 snowpit & $2015-2016$ & 0.8 & 241 & 179 & 91078 & 1.4 & 0.8 & 3.5 & -0.34 & 1.5 & 0.1 & 4.6 \\
\hline DSS1213 core & $1987-2012$ & 25 & 115 & 106 & 4355 & 2 & & 0.2 & 0.67 & 0.06 & 1.8 & 0.1 \\
\hline DSS0506 core & 1927-1986 & 59 & 77 & 74 & 571 & 3.3 & & 9.7 & 0.88 & 0.57 & 2.5 & 0.6 \\
\hline
\end{tabular}

Table 2. Correlations between bromine and iodine enrichments and first-year sea ice (FYSI) areas calculated for two sectors adjacent to Law Dome. Correlations that are significant at the $99 \%$ level or above are shown in bold.

\begin{tabular}{lrrrrr}
\hline & & \multicolumn{2}{c}{ FYSI $90-110^{\circ} \mathrm{E}$} & \multicolumn{2}{c}{ FYSI $110-130^{\circ} \mathrm{E}$} \\
\cline { 3 - 6 } Ln (Br ${ }_{\text {enr }}$ ) & \# years & $r^{2}$ & $p$ value & $r^{2}$ & $p$ value \\
\hline Jan-Dec (summer-summer) & 35 & $\mathbf{0 . 3 5 7}$ & $<\mathbf{0 . 0 0 1}$ & 0.006 & $\mathrm{~ns}$ \\
Jul-Jun (winter-winter) & 35 & 0.17 & $<0.05$ & $\mathbf{0 . 2 0}$ & $<\mathbf{0 . 0 1}$ \\
Sep-Nov (Spring only) & 35 & 0.18 & $<0.05$ & 0.02 & ns \\
\hline & & FYSI $90-110^{\circ} \mathrm{E}$ & FYSI $110-130^{\circ} \mathrm{E}$ \\
\cline { 3 - 6 } & \# years & $r^{2}$ & $p$ value & $r^{2}$ & $p$ value \\
Ienr & 12 & 0.07 & $\mathrm{~ns}$ & 0.24 & $\mathrm{~ns}$ \\
Jan-Dec (summer-summer) & 12 & 0.02 & $\mathrm{~ns}$ & 0.03 & $\mathrm{~ns}$ \\
Jul-Jun (winter-winter) & 12 & 0.09 & $\mathrm{~ns}$ & 0.005 & $\mathrm{~ns}$ \\
Sep-Nov (spring only) & & & & & \\
\hline
\end{tabular}

$\mathrm{ns}=$ indicates a non-significant correlation

$110^{\circ} \mathrm{E}$ FYSI due to the smoothing effect caused by the averaging of consecutive spring/summer periods.

\subsection{Bromine enrichment as a sea ice proxy}

On the basis of the significant correlation between bromine enrichment at Law Dome and $90-110^{\circ}$ E FYSI, we consider the implications for reconstructing past sea ice area at Law Dome. Figure 5 shows Law Dome $\ln \left(\mathrm{Br}_{\mathrm{enr}}\right)$ and MSA (Curran et al., 2003) since $1927 \mathrm{CE}$ as well as the $90-110^{\circ} \mathrm{E}$ FYSI data plotted as an anomaly from the average of the data, to better display FYSI trends. We firstly note that a selection of running-mean smoothing filters has been applied to such data previously, such as 3- and 20-year means (Curran et al., 2003) and 11-year means (Abram et al., 2010). Here we follow the latter and show 11-year means as well as the individual annual data points.

When comparing two proxies purporting to represent the same phenomenon it is vital to consider the different physical processes involved in the proxy generation, transport and deposition. We note that MSA is produced biologically and, for the Law Dome sector, has been quantitatively linked to the opening of sea-ice-covered seawater during the summer and autumn seasons. Bromine enrichment occurs primarily in spring/summer and is dependent upon the presence of FYSI (Saiz-Lopez and von Glasow, 2012). Due to the 11-year smoothing applied to the data, influences of seasonal patterns, factors influencing biological growth, relations to sea ice and transport efficacy should be minimized for the comparison of bromine enrichment and MSA trends at Law Dome.

Some differences are seen among the sea ice trends indicated by MSA and bromine at Law Dome over the 20th century (Fig. 5). Both proxies display substantial multidecadal variability, so any long-term trend is here treated with caution. In the cases of both bromine and MSA, simple linear regression indicates small declining trends for both species. Bromine enrichment values are greater during the period 1940-1950 and 1975-1985 while the highest MSA concentrations are observed during the period 1945-1955. Bromine and MSA both point toward greater sea ice area during the period from 1945-1950 but diverge between 1955 and 1970 . The cause for this divergence is not yet known, but before speculating on a possible cause, these trends should be confirmed by measurements of other snow and ice samples from Law Dome as well as other sectors of the East Antarctic coast. The possible influence of multidecadal-scale climate variability, such as the Interdecadal Pacific Oscillation (IPO), on the bromine record is discussed in detail in Sect. 3.4, but will briefly be considered here. IPO forcing of Antarctic sea ice area has been demonstrated at decadal timescales (Meehl et al., 2016), with the negative IPO phase triggering sea level pressure (SLP) and near-surface wind changes that can influence sea ice expansion, storm tracks and potentially nutrient supply to DMS-producing algal communities. Smaller magnitudes of change are observed in MSA over the 20th century, 


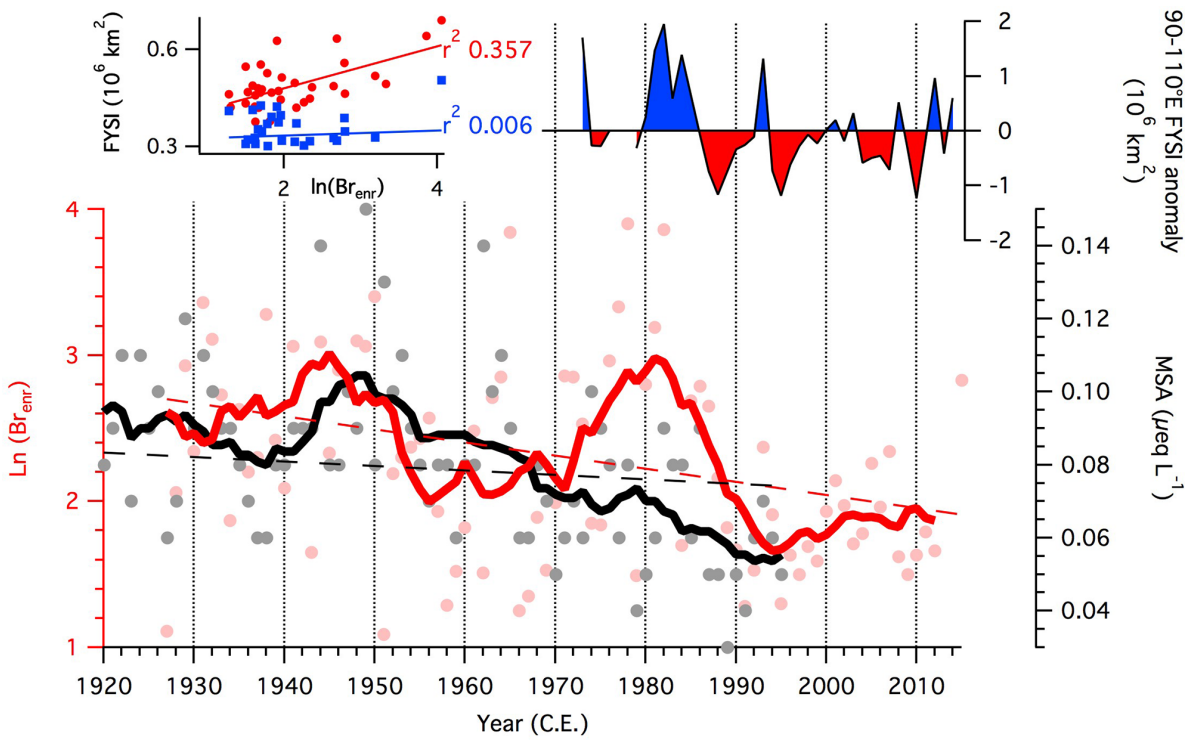

Figure 5. Bromine enrichment ( $\mathrm{Br}_{\mathrm{enr}}$, red), MSA (black) and first-year sea ice (FYSI) at Law Dome. Bromine enrichment and MSA data are shown as annual averages (circles) as well as 11-year (thick lines) running means. Linear regression trends are shown as dotted lines. FYSI areas in the $90-110^{\circ} \mathrm{E}$ sector (top right) are shown as annual anomalies from the 1973-2014 average. Shown in the top left panel are correlations between $\mathrm{Br}_{\mathrm{enr}}$ and FYSI areas in the $90-110^{\circ} \mathrm{E}$ (red) and $110-130^{\circ} \mathrm{E}$ (blue) sector.

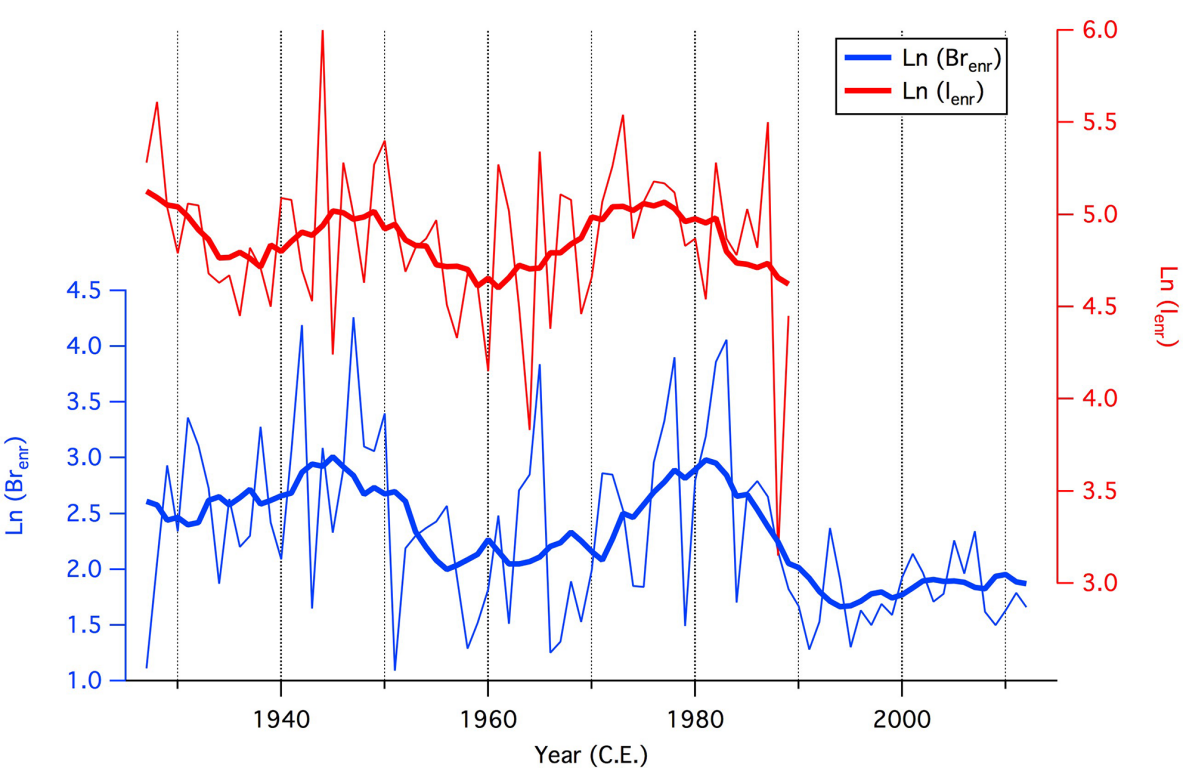

Figure 6. Time series of bromine and iodine enrichment beyond sea salt concentrations. As described in Sect. 3.2, sea salt is represented by sodium. Bromine and iodine show similar trends, pointing to a common source of variability.

compared to $\mathrm{Br}_{\mathrm{enr}}$. Despite the short time period available, satellite-based observations of FYSI display positive anomalies before 1985 and negative anomalies in the last decades (Fig. 5) which are consistent with recent trends of both MSA and $\mathrm{Br}_{\mathrm{enr}}$.

\section{4 lodine enrichment}

Iodine enrichment in sea ice could be explained by complex heterogeneous reactions that take place above seasonal sea ice releasing gas-phase iodine and particulate species. Peak I concentrations have been found in winter snow strata at Law Dome (Spolaor et al., 2014) and Neumayer station (Frieß et al., 2010), suggesting surface re-emission and/or remobilization during the austral summer. There is no sig- 

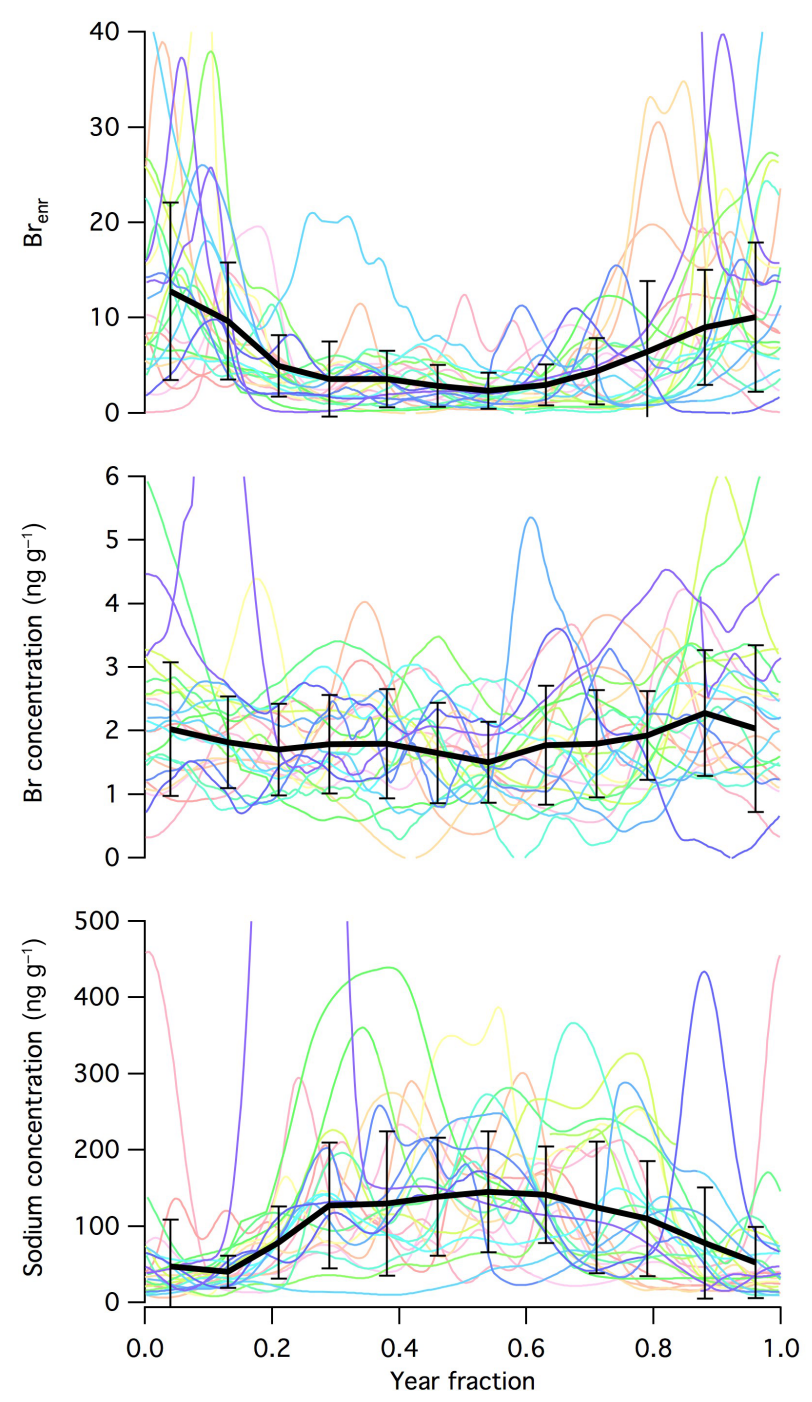

Figure 7. Seasonality of sodium and bromine concentrations and bromine enrichment $\left(\mathrm{Br}_{\mathrm{enr}}\right)$ in the DSS1213 firn core. Each colour corresponds to 1 year of data with the same year represented by the same colour. The year fraction has been separated into 12 months, with 0.04 representing January and 0.96 representing December. The error bars show 1 SD for the 26 years sampled.

nificant correlation between $\mathrm{Br}_{\mathrm{enr}}$ and $\mathrm{I}_{\mathrm{enr}}$ signals on an annual basis $\left(r^{2}=0.05, p<0.1\right)$. This lack of significant correlation might be related to the different iodine emissions and recycling mechanisms over sea ice: (i) emission of iodine from sea-ice-enhanced bioproductivity and subsequent upwards migration through brine channels (Saiz-Lopez et al., 2015); (ii) photochemical reactions over iodate frozen salts (Spolaor et al., 2012) and (iii) atmospheric release of gasphase iodine from triiodide production via iodide oxidation in frozen solution (Kim et al., 2016). Another indicator of the complex ocean-sea ice-atmosphere interrelation arises from the statistical comparison with FYSI records (Table 2). Correlation significance levels for $\mathrm{I}_{\mathrm{enr}}$ are consistently be-

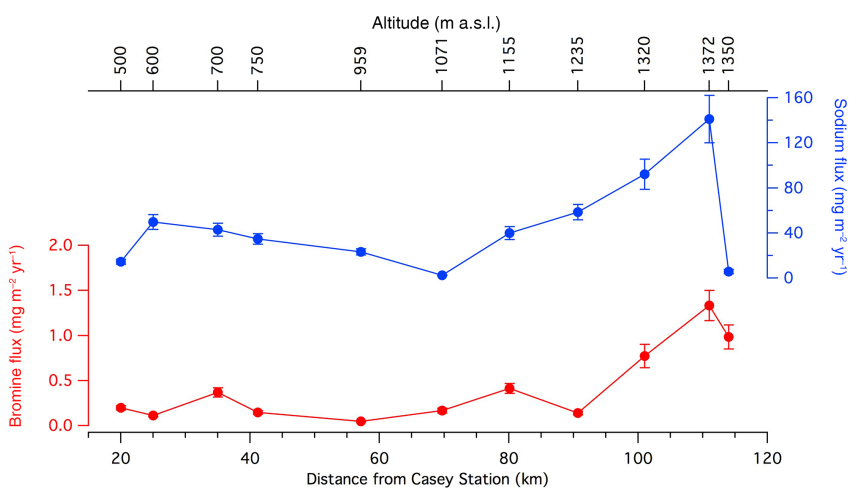

Figure 8. Fluxes of sodium and bromine along the 2016 Law Dome Traverse (indicated in Fig. 1). Uncertainties include uncertainties in the analysis $(9 \% \mathrm{Br}, 4 \% \mathrm{Na})$ and accumulation $(10 \%)$.

low the $95 \%$ level and correlation coefficients are generally low. The strongest correlation of $\mathrm{I}_{\mathrm{enr}}$ is between the summersummer (calendar year) averaged signal and the $110-130^{\circ} \mathrm{E}$ FYSI sector, but this is still below the $95 \%$ significance level.

Correlation between 11-year smoothed $\mathrm{I}_{\mathrm{enr}}$ and $\mathrm{Br}_{\mathrm{enr}}$ records (Fig. 6) is significant $\left(r^{2}=0.269, p<0.001\right)$ suggesting a long-term (decadal scale) common driver controlling halogen deposition in coastal Antarctica. The iodine enrichment time series shows a similar pattern to that of bromine enrichment, with higher values particularly during the 1940s and back from negative to positive in the 1970s (Fig. 6). These periods coincide with rapid changes in the Interdecadal Pacific Oscillation (IPO) phase from positive to negative in the 1940s and back from negative to positive in the 1970s. The IPO is a low-frequency climate mode related to the El Niño-Southern Oscillation which operates on multidecadal timescales. It affects climate variability at the multidecadal scale across and beyond the Pacific Basin (Power et al., 1999; Vance et al., 2015). Impurities deposited at Law Dome have been demonstrated to faithfully reflect IPO variability (Vance et al., 2015) and reanalysis data indicate a strong IPO signal in the Indian Ocean (Vance et al., 2016). Furthermore, recent work has demonstrated an IPO forcing of Antarctic sea ice area at decadal timescales, with the late-1990s shift to a negative IPO phase triggering SLP and near-surface wind changes that are conducive and consistent with an expansion in sea ice in all seasons across multiple regions of the Antarctic seasonal ice zone (Meehl et al., 2016). Thus the overall correlation between iodine and bromine enrichment may be linked to decadal-scale states of the atmosphere-ocean-sea ice system in the Indian sector of the Southern Ocean. It must be noted that, in addition to larger-scale influences of atmospheric transport and oceanrelated sea ice variability, both $\mathrm{I}_{\mathrm{enr}}$ and $\mathrm{Br}_{\mathrm{enr}}$ are calculated using $\mathrm{Na}$ as an indicator of sea salt content in the samples. The possibility of an IPO-related signal, transmitted through $\mathrm{Na}$ concentrations, cannot be discounted from contributing 
to the apparent correlation of $\mathrm{I}_{\mathrm{enr}}$ and $\mathrm{Br}_{\mathrm{enr}}$ in DSS0506 core samples.

\subsection{Bromine seasonality}

Due to the availability of consistent and highly resolved data from the DSS1213 core, it is possible to investigate seasonal distributions of sodium and bromine at Law Dome. The seasonal cycle of major and minor ions has been previously reported for Law Dome (Curran et al., 1998) but for bromine only 4 years are available (Spolaor et al., 2014). Here we present the DSS1213 record, spanning the period 1987 to 2012. The seasonality of sodium and $\mathrm{Br}_{\text {enr }}$ are shown in Fig. 7. Sodium shows a broad period of high concentrations from April to September, with lower concentrations during the summer. This pattern broadly agrees with that reported by Curran et al. (1998) although those authors found a sharper sodium peak in late winter, associated with both the local sea ice maximum and the strongest local wind fields. We also note that the highest concentration of sodium is found in March-April and is likely due to one of "a small number of large storm events which occasionally occur early in the year, lofting higher concentrations of sea-salt aerosol onto the summit of the dome" (Curran et al., 1998).

The trend observed for $\mathrm{Br}_{\mathrm{enr}}$ is one of lower values in winter and higher values from November to February. There is high variability in the sodium signal throughout the year, whereas the $\mathrm{Br}_{\text {enr }}$ signal is most variable during the summer months. The seasonality of $\mathrm{Br}_{\mathrm{enr}}$ found here confirms that suggested by the 4-year data series presented by Spolaor et al. (2014), with a broad summer peak in $\mathrm{Br}_{\text {enr }}$. Satellite observations of atmospheric $\mathrm{BrO}$ in polar regions suggest an early spring peak in bromine activity in Antarctica (Spolaor et al., 2014), thereby implying that additional processes may be occurring in the snowpack during the summer after the peak atmospheric bromine explosion has occurred. While snowpack remobilization at Law Dome is minimal, it might be the case that photochemically driven heterogeneous recycling of bromine occurs in the snowpack after the springtime occurrence of the bromine explosion. This effect requires further investigation, from satellite and ground-based observations to weekly surface snow sampling, to be fully characterized and understood.

\subsection{Bromine deposition across Law Dome}

Variability in sodium and bromine was investigated along the transect line from Casey station to the Law Dome summit. The traverse route is indicated in Fig. 1, where 11 samples were collected over a period of $4 \mathrm{~h}$ on the 10 February 2016. Conditions were clear with low wind and good visibility. Details of the sampling sites are included in Table S1 (Supplement). The sodium and bromine results for each station are shown in Fig. 8.
Substantial variability can be seen along the traverse, with increasing fluxes of sodium and bromine approaching the Law Dome summit. It should be noted that the sampling was undertaken on the "lee side" of Law Dome, across a region which generally exhibits low annual accumulation on the order of $<200 \mathrm{~kg} \mathrm{~m}^{-2}$. The final $25 \mathrm{~km}$ of the traverse sees a threefold increase in annual accumulation to $>600 \mathrm{~kg} \mathrm{~m}^{-2}$. Higher fluxes of $\mathrm{Na}$ and $\mathrm{Br}$ in zones of higher accumulation suggest that both $\mathrm{Na}$ and $\mathrm{Br}$ are wet-deposited over the eastern half of Law Dome. The data presented here represent a first attempt to capture the surface variability of sodium and bromine across Law Dome. Future expeditions to Law Dome should incorporate a procedure for surface sampling along the traverse line and ideally further east toward the origin of the precipitation pathway over Law Dome.

\section{Conclusions}

The Law Dome site is ideal for studies of sea ice proxies, due to the regular and high level of annual precipitation allowing detailed studies of seasonality as well as the optimal preservation conditions. We find here that bromine enrichment over the past century displays some similarity to that of MSA, which has been previously used for reconstruction of local sea ice extent. The bromine-based reconstruction of the sea ice area in the $90-110^{\circ} \mathrm{E}$ Antarctic sector suggests a reduction of sea ice area over the 20th century and hence is supportive of previous findings based on MSA. In agreement with satellite observations there is some indication of an increase in sea ice area since 1990.

In agreement with a previous study of halogen seasonality at Law Dome, we find that bromine enrichment displays regular seasonality with a broad summer peak. Iodine enrichment appears to be correlated to bromine enrichment on decadal scales but not annual scales, suggesting that despite their different chemical processes of emission and deposition, a multidecadal climate signal such as the Interdecadal Pacific Oscillation may act as a common influence on the enrichment of both halogen elements.

More extensive sampling across Law Dome and further inland should be considered in future field seasons. Samples collected during a traverse from Casey station to Law Dome DSS site display a consistent increase in deposition fluxes from west to east, as expected from the easterly cyclonic systems responsible for the precipitation at Law Dome. Additional traverse data should be collected at the next available opportunity and ideally, the traverse should be extended over the dome summit and onto the eastern side of the dome. The Law Dome halogens record presented here should be extended further back in time and similar studies should be undertaken at other Antarctic locations, to ensure consistency and validation of the sea ice reconstruction presented here. 


\section{Data availability}

Data are publicly available online through the PANGAEA data repository (https://doi.pangaea.de/10.1594/PANGAEA. 868431).

\section{The Supplement related to this article is available online at doi:10.5194/cp-13-171-2017-supplement.}

Competing interests. The authors declare that they have no conflicts of interest.

Acknowledgements. The research leading to these results received funding from the European Research Council under the European Union's Seventh Framework Programme (FP7/2007-2013), grant agreement no. 610055 "Ice2ice". The Australian Antarctic Division provided funding and logistical support for the DSS ice cores (AAS projects 4061 and 4062). Gunnar Spreen was supported by the Institutional Strategy of the University of Bremen, funded by the German Excellence Initiative. All correlations and associated confidence levels reported here have been calculated using the program $\mathrm{R}$ via the RStudio interface. We thank the reviewers for their helpful suggestions and constructive comments.

Edited by: E. Brook

Reviewed by: two anonymous referees

\section{References}

Abram, N. J., Mulvaney, R., Wolff, E. W., and Mudelsee, M.: Ice core records as sea ice proxies: An evaluation from the Weddell Sea region of Antarctica, J. Geophys. Res., 112, D15101, doi:10.1029/2006JD008139, 2007.

Abram, N. J., Wolff, E. W., and Curran, M. A. J.: A review of sea ice proxy information from polar ice cores, Quaternary Sci. Rev., 79, 168-183, doi:10.1016/j.quascirev.2013.01.011, 2013.

Atkinson, H. M., Huang, R. J., Chance, R., Roscoe, H. K., Hughes, C., Davison, B., Schönhardt, A., Mahajan, A. S., Saiz-Lopez, A., Hoffmann, T., and Liss, P. S.: Iodine emissions from the sea ice of the Weddell Sea, Atmos. Chem. Phys., 12, 11229-11244, doi:10.5194/acp-12-11229-2012, 2012.

Brooks, S. B., Saiz-Lopez, A., Skov, H., Lindberg, S. E., Plane, J. M. C., and Goodsite, M. E.: The mass balance of mercury in the springtime arctic environment, Geophys. Res. Lett., 33, doi:10.1029/2005GL025525, 2006.

Burn-Nunes, L. J., Vallelonga, P., Loss, R. D., Burton, G., Moy, A., Curran, M., Hong, S., Smith, A. M., Edwards, R., Morgan, V., and Rosman, K. J. R.: Seasonal variability in the input of lead, barium and indium to Law Dome, Antarctica, Geochim. Cosmochim. Ac., 75, 1-20, doi:10.1016/j.gca.2010.09.037, 2011.

Cavalieri, D. J., Parkinson, C. L., Gloersen, P., and Zwally, H. J.: Sea Ice Concentrations from Nimbus-7 SMMR and DMSP SSM/I-SSMIS Passive Microwave Data, Version 1, NASA National Snow and Ice Data Center Distributed Active Archive Center, Boulder, Colorado USA, 104, 15803-15814, doi:10.5067/8GQ8LZQVL0VL, 1996 (updated yearly).
Cavalieri, D. J., Parkinson, C. L., Gloersen, P., Comiso, J. C., and Zwally, H. J.: Deriving long-term time series of sea ice cover from satellite passive-microwave multisensor data sets, J. Geophys. Res., 104, 15803-15814, doi:10.1029/1999JC900081, 1999.

Crosta, X., Sturm, A., Armand, L., and Pichon, J.-J.: Late Quaternary sea ice history in the Indian sector of the Southern Ocean as recorded by diatom assemblages, Mar. Micropaleontol., 50, 209-223, doi:10.1016/S0377-8398(03)00072-0, 2004.

Curran, M. and Palmer, A. S.: Suppressed ion chromatography methods for the routine determination of ultra low level anions and cations in ice cores, J. Chromatogr. A, 919, 1-7, doi:10.1016/S0021-9673(01)00790-7, 2001.

Curran, M. A. J., van Ommen, T. D., and Morgan, V. I.: Seasonal characteristics of the major ions in the high-accumulation Dome Summit South ice core, Law Dome, Antarctica, Ann. Glaciol., 27, 385-390, doi:10.3198/1998AoG27-1-385-390, 1998.

Curran, M. A. J., Tas D. van Ommen, Morgan, V. I., Phillips, K. L., and Palmer, A. S.: Ice core evidence for Antarctic sea ice decline since the 1950s, Science, 302, 1203-1206, doi:10.1126/science.1087888, 2003.

Ellis, A., Edwards, R., Saunders, M., Chakrabarty, R. K., Subramanian, R., van Riessen, A., Smith, A. M., Lambrinidis, D., Nunes, L. J., Vallelonga, P., Goodwin, I. D., Moy, A. D., Curran, M. A. J., and van Ommen, T. D.: Characterizing black carbon in rain and ice cores using coupled tangential flow filtration and transmission electron microscopy, Atmos. Meas. Tech., 8, 3959-3969, doi:10.5194/amt-8-3959-2015, 2015.

Fetterer, F., Knowles, K., Meier, W., and Savoie, M.: Sea Ice Index, 2009-2012, doi:10.7265/N5QJ7F7W, 2002 (updated daily).

Frieß, U., Deutschmann, T., Gilfedder, B. S., Weller, R., and Platt, U.: Iodine monoxide in the Antarctic snowpack, Atmos. Chem. Phys., 10, 2439-2456, doi:10.5194/acp-10-2439-2010, 2010.

Granfors, A., Ahnoff, M., Mills, M. M., and Abrahamsson, K.: Organic iodine in Antarctic sea ice: A comparison between winter in the Weddell Sea and summer in the Amundsen Sea, J. Geophys. Res., 119, 2276-2291, doi:10.1002/2014JG002727, 2014.

Hylander, L. D. and Goodsite, M. E.: Environmental costs of mercury pollution, Sci. Total Env., 368, 352-370, doi:10.1016/j.scitotenv.2005.11.029, 2006.

Impey, G. A., Shepson, P. B., Hastie, D. R., Barrie, L. A., and Anlauf, K. G.: Measurements of photolyzable chlorine and bromine during the Polar Sunrise Experiment 1995, J. Geophys. Res., 102, 16005-16010, doi:10.1029/97JD00851, 1997.

Jacka, J.: Antarctic CRC and Australian Antarctic Division Climate Data Set - Northern extent of Antarctic sea ice Australian Antarctic Data Centre - CAASM Metadata, https://data.aad.gov. au/metadata/records/climate_sea_ice, 1999.

Kim, K., Yabushita, A., Okumura, M., Saiz-Lopez, A., Cuevas, C. A., Blaszczak-Boxe, C. S., Min, D. W., Yoon, H.-I., and Choi, W.: Production of Molecular Iodine and Tri-iodide in the Frozen Solution of Iodide: Implication for Polar Atmosphere, Environ. Sci. Technol., 50, 1280-1287, doi:10.1021/acs.est.5b05148, 2016.

Legrand, M., Yang, X., Preunkert, S., and Theys, N.: Year-round records of sea salt, gaseous, and particulate inorganic bromine in the atmospheric boundary layer at coastal (Dumont d'Urville) and central (Concordia) East Antarctic sites, J. Geophys. Res.Atmos., 121, 997-1023, doi:10.1002/2015JD024066, 2016. 
Levine, J. G., Yang, X., Jones, A. E., and Wolff, E. W.: Sea salt as an ice core proxy for past sea ice extent: A processbased model study, J. Geophys. Res.-Atmos., 119, 5737-5756, doi:10.1002/2013JD020925, 2014.

McConnell, J. R., Lamorey, G. W., Lambert, S. W., and Taylor, K. C.: Continuous ice-core chemical analyses using inductively coupled plasma mass spectrometry, Environ. Sci. Technol., 36, 7-11, doi:10.1021/es011088z, 2002.

McMorrow, A., van Ommen, T. D., Morgan, V., and Curran, M. A. J.: Ultra-high-resolution seasonality of trace-ion species and oxygen isotope ratios in Antarctic firn over four annual cycles, Ann. Glaciol., 39, 34-40, doi:10.3189/172756404781814609, 2004.

Meehl, G. A., Arblaster, J. M., Bitz, C. M., Chung, C. T. Y., and Teng, H.: Antarctic sea-ice expansion between 2000 and 2014 driven by tropical Pacific decadal climate variability, Nat. Geosci., 9, 590-595, doi:10.1038/ngeo2751, 2016.

Morgan, V. and van Ommen, T. D.: Seasonality in late-Holocene climate from ice-core records, The Holocene, 7, 351-354, doi:10.1177/095968369700700312, 1997.

Morgan, V., Wookey, C. W., Li, J., van Ommen, T. D., Skinner, W., and Fitzpatrick, M. F.: Site information and initial results from deep ice drilling on Law Dome, Antarctica, J. Glaciol., 43, 3-10, doi:10.3198/1997JoG43-143-3-10, 1997.

Nerentorp Mastromonaco, M., Gårdfeldt, K., Jourdain, B., Abrahamsson, K., Granfors, A., Ahnoff, M., Dommergue, A., Méjean, G., and Jacobi, H. W.: Antarctic winter mercury and ozone depletion events over sea ice, Atmos. Environ., 129, 125-132, doi:10.1016/j.atmosenv.2016.01.023, 2016.

Palmer, A. S., van Ommen, T. D., Curran, M. A. J., Morgan, V. I., Souney, J. M., and Mayewski, P. A.: High precision dating of volcanic events (A.D. 1301-1995) using ice cores from Law Dome, Antarctica, J. Geophys. Res., 106, 28089-28095, doi:10.1029/2001JD000330, 2001.

Parkinson, C. L. and Cavalieri, D. J.: Antarctic sea ice variability and trends, 1979-2010, The Cryosphere, 6, 871-880, doi:10.5194/tc-6-871-2012, 2012.

Parkinson, C. L., Comiso, J. C., and Zwally, H. J.: Nimbus-5 ESMR Polar Gridded Sea Ice Concentrations, Version 1, edited by: Meier, W. and Stroeve, J., NASA National Snow and Ice Data Center Distributed Active Archive Center, Boulder, Colorado USA, 2004.

Plummer, C. T., Curran, M. A. J., van Ommen, T. D., Rasmussen, S. O., Moy, A. D., Vance, T. R., Clausen, H. B., Vinther, B. M., and Mayewski, P. A.: An independently dated 2000-yr volcanic record from Law Dome, East Antarctica, including a new perspective on the dating of the 1450s CE eruption of Kuwae, Vanuatu, Clim. Past, 8, 1929-1940, doi:10.5194/cp-8-1929-2012, 2012.

Power, S., Casey, T., Folland, C., Colman, A., and Mehta, V.: Interdecadal modulation of the impact of ENSO on Australia, Clim. Dyn., 15, 319-324, doi:10.1007/s003820050284, 1999.

Pratt, K. A., Custard, K. D., Shepson, P. B., Douglas, T. A., Pohler, D., General, S., Zielcke, J., Simpson, W. R., Platt, U., Tanner, D. J., Gregory Huey, L., Carlsen, M., and Stirm, B. H.: Photochemical production of molecular bromine in Arctic surface snowpacks, Nat. Geosci., 6, 351-356, doi:10.1038/ngeo1779, 2013.

Roberts, J., Plummer, C., Vance, T., van Ommen, T., Moy, A., Poynter, S., Treverrow, A., Curran, M., and George, S.: A 2000year annual record of snow accumulation rates for Law Dome,
East Antarctica, Clim. Past, 11, 697-707, doi:10.5194/cp-11697-2015, 2015.

Röthlisberger, R., Crosta, X., Abram, N. J., Armand, L., and Wolff, E. W.: Potential and limitations of marine and ice core sea ice proxies: an example from the Indian Ocean sector, Quaternary Sci. Rev., 29, 296-302, doi:10.1016/j.quascirev.2009.10.005, 2010.

Saiz-Lopez, A. and von Glasow, R.: Reactive halogen chemistry in the troposphere, Chem. Soc. Rev., 41, 6448-6472, doi:10.1039/C2CS35208G, 2012.

Saiz-Lopez, A., Mahajan, A. S., Salmon, R. A., Bauguitte, S. J. B., Jones, A. E., Roscoe, H. K., and Plane, J. M. C.: Boundary Layer Halogens in Coastal Antarctica, Science, 317, 348-351, doi:10.1126/science.1141408, 2007.

Saiz-Lopez, A., Plane, J. M. C., Baker, A. R., Carpenter, L. J., von Glasow, R., Gomez Martin, J. C., McFiggans, G., and Saunders, R. W.: Atmospheric Chemistry of Iodine, Chem. Rev., 112, 1773-1804, doi:10.1021/cr5006638, 2012.

Saiz-Lopez, A., Baidar, S., Cuevas, C. A., Koenig, T. K., Fernandez, R. P., Dix, B., Kinnison, D. E., Lamarque, J., Campos, T. L., and Volkamer, R.: Injection of iodine to the stratosphere, Geophys. Res. Lett., 42, 1-8, doi:10.1002/2015GL064796, 2015.

Simpson, W. R., von Glasow, R., Riedel, K., Anderson, P., Ariya, P., Bottenheim, J., Burrows, J., Carpenter, L. J., Frievü, U., Goodsite, M. E., Heard, D., Hutterli, M., Jacobi, H. W., Kaleschke, L., Neff, B., Plane, J., Platt, U., Richter, A., Roscoe, H., Sander, R., Shepson, P., Sodeau, J., Steffen, A., Wagner, T., and Wolff, E.: Halogens and their role in polar boundary-layer ozone depletion, Atmos. Chem. Phys., 7, 4375-4418, doi:10.5194/acp-74375-2007, 2007.

Simpson, W. R., Brown, S. S., Saiz-Lopez, A., Thornton, J. A., and von Glasow, R.: Tropospheric Halogen Chemistry: Sources, Cycling, and Impacts, Chem. Rev., 115, 4035-4062, doi:10.1021/cr5006638, 2015.

Spolaor, A., Vallelonga, P., Gabrieli, J., Kehrwald, N., Turetta, C., Cozzi, G., Plane, J. M. C., Boutron, C., and Barbante, C.: Speciation analysis of iodine and bromine at picogram-pergram levels in Polar Ice, Anal. Bioanal. Chem., 405, 647-654, doi:10.1007/s00216-012-5806-0, 2012.

Spolaor, A., Gabrieli, J., Martma, T., Kohler, J., Björkmann, M., Isaksson, E., Varin, C., Vallelonga, P., Plane, J. M. C., and Barbante, C.: Sea ice dynamics influence halogen deposition to Svalbard, The Cryosphere, 7, 1645-1658, doi:10.5194/tc-7-16452013, 2013a.

Spolaor, A., Vallelonga, P., Plane, J. M. C., Kehrwald, N., Gabrieli, J., Varin, C., Turetta, C., Cozzi, G., Kumar, R., Boutron, C., and Barbante, C.: Halogen species record Antarctic sea ice extent over glacial-interglacial periods, Atmos. Chem. Phys., 13, 66236635, doi:10.5194/acp-13-6623-2013, 2013 b.

Spolaor, A., Vallelonga, P., Gabrieli, J., Martma, T., Björkman, M. P., Isaksson, E., Cozzi, G., Turetta, C., Kjær, H. A., Curran, M. A. J., Moy, A. D., Schönhardt, A., Blechschmidt, A. M., Burrows, J. P., Plane, J. M. C., and Barbante, C.: Seasonality of halogen deposition in polar snow and ice, Atmos. Chem. Phys., 14, 96139622, doi:10.5194/acp-14-9613-2014, 2014.

Spolaor, A., Opel, T., McConnell, J. R., Maselli, O. J., Spreen, G., Varin, C., Kirchgeorg, T., Fritzsche, D., Saiz-Lopez, A., and Vallelonga, P.: Halogen-based reconstruction of Russian Arctic sea ice area from the Akademii Nauk ice core (Severnaya 
Zemlya), The Cryosphere, 10, 245-256, doi:10.5194/tc-10-2452016, 2016a.

Spolaor, A., Vallelonga, P., Turetta, C., Maffezzoli, N., Cozzi, G., Gabrieli, J., Barbante, C., Goto-Azuma, K., Saiz-Lopez, A., Cuevas, C. A., and Dahl-Jensen, D.: Canadian Arctic sea ice history reconstructed from bromine in the Greenland NEEM ice core, Sci. Rep., 6, 33925, doi:10.1038/srep33925, 2016 b.

Thomas, E. R. and Abram, N. J.: Ice core reconstruction of sea ice change in the Amundsen-Ross Seas since 1702 A.D., Geophys. Res. Lett., 43, 5309-5317, doi:10.1002/2016GL068130, 2016.

Toyota, K., McConnell, J. C., Staebler, R. M., and Dastoor, A. P.: Air-snowpack exchange of bromine, ozone and mercury in the springtime Arctic simulated by the 1-D model PHANTAS - Part 1: In-snow bromine activation and its impact on ozone, Atmos. Chem. Phys., 14, 4101-4133, doi:10.5194/acp-14-41012014, 2014.

Turekian, K. K.: Oceans, Prentice-Hall, New Jersey, 120 pp., 1968. Vallelonga, P., Barbante, C., Cozzi, G., Gaspari, V., Candelone, J.P., van de Velde, K., Morgan, V. I., Rosman, K. J. R., Boutron, C. F., and Cescon, P.: Elemental indicators of natural and anthropogenic aerosol inputs to Law Dome, Antarctica, Ann. Glaciol., 39, 169-174, doi:10.3189/172756404781814483, 2004.
Vallelonga, P., Maffezzoli, N., Moy, A. D., Curran, M. A. J., Vance, T. R., Edwards, R. L., Hughes, G., Barker, E., Spreen, G., Saiz-Lopez, A., Corella, J. P., Cuevas, C. A., and Spolaor, A.: Law Dome Br, Na, I (1927-2016) and sea ice (1973-2015), doi:10.1594/PANGAEA.868431, 2016.

Vance, T. R., Roberts, J. L., Plummer, C. T., Kiem, A. S., and van Ommen, T. D.: Interdecadal Pacific variability and eastern Australian mega-droughts over the last millennium, Geophys. Res. Lett., 42, 129-137, doi:10.1002/2014GL062447, 2015.

Vance, T. R., Roberts, J. L., Moy, A. D., Curran, M. A. J., Tozer, C. R., Gallant, A. J. E., Abram, N. J., van Ommen, T. D., Young, D. A., Grima, C., Blankenship, D. D., and Siegert, M. J.: Optimal site selection for a high-resolution ice core record in East Antarctica, Clim. Past, 12, 595-610, doi:10.5194/cp-12595-2016, 2016.

Zhao, X., Strong, K., Adams, C., Schofield, R., Yang, X., Richter, A., Friess, U., Blechschmidt, A.-M., and Koo, J.-H.: A case study of a transported bromine explosion event in the Canadian high arctic, J. Geophys. Res. Atmos., 121, 457-477, doi:10.1002/2015JD023711, 2016. 